\title{
PENERAPAN KONSINYASI TERHADAP OBJEK YANG SUDAH DIJAMINKAN MELALUI HAK TANGGUNGAN
}

\section{APPLICATION OF CONSIGNMENT TO OBJECTS THAT HAVE BEEN GUARANTEED THROUGH MORTGAGE RIGHTS}

\author{
Ragga Bimantara \\ Anggota Komite Tetap Advokasi Hukum Bisnis dan Ekonomi Kadin Jawa Barat \\ Mahasiswa Program Pascasarjana Fakultas Hukum Unpad, Bandung \\ Email : Ragga.Bimantara@yahoo.com
}

\section{Etty Mulyati}

Dosen Fakultas Hukum Universitas Padjadjaran, Bandung

Email : etty.mulyati@unpad.ac.id

\section{Isis Ikhwansyah}

Universitas Padjadjaran, Bandung email : ikhwansyahisis@gmail.com

\begin{abstract}
Infrastructure development for the public interest is one of the country's obligations in the field of public service that are appropriate and needed by the community. But, the development that will be carried out by the government is not impossible to get many obstacles in its work, one of them is related to land acquisition. So, with the aim of the public interest, government must be able to carry out land acquisition with the approval from the landowner or without the approval from the landowner. Therefore, the discussion in this research is to find out and analyze how the application of consignment in terms of land acquisition for the public interest and how to settle compensation if the released object is under collateral security. This type of research uses normative legal research methods that focus on normative juridical law, as well as primary, secondary and tertiary legal materials. The results of this study show that for the sake of public interest, the government can apply the consignment request to the land object's owner through the district court, by referring to Perma No. 3 of 2016. Government also can apply the consignment request to the object that being pledged, provided that the debtor receives written approval from the creditor when taking compensation.
\end{abstract}

Keywords : Compensation; Consignment; Mortgage Rights; Public Interest.

\begin{abstract}
Abstrak
Pembangunan Infrastruktur demi kepentingan umum merupakan salah satu kewajiban negara dalam mewujudkan tanggung jawabnya di bidang fasilitas pelayanan umum yang layak dan diperlukan oleh masyarakat, namun pembangunan yang akan dikerjakan oleh pemerintah bukan tidak mungkin mengalami kendala dalam pekerjaanya, salah satunya yaitu terkait pembebasan lahan. Sehingga pemerintah dengan tujuan kepentingan umum, harus dapat melakukan pembebasan lahan dengan persetujuan pemilik lahan ataupun tanpa persetujuan pemilik lahan. Maka dari itu pembahsan pada penelitian ini adalah untuk mengetahui maupun menganalisis bagaimana penerapan konsinyasi terhadap pembebasan tanah untuk kepentingan umum dan bagaimana penyelesaian ganti rugi apabila objek yang akan dibebaskan sedang dalam jaminan hak tanggungan. Jenis penelitian ini menggunakan
\end{abstract}


metode penelitian hukum normatif yang menitik beratkan pada hukum yuridis normatif, maupun bahan hukum primer, sekunder dan tersier. Hasil penelitian menunjukan bahwa demi kepentingan umum pemerintah dapat mengajukan permohonan konsinyasi melalui pengadilan negeri terhadap pemilik objek tanah dengan mengacu kepada Perma Nomor 3 tahun 2016, dan juga termasuk kepada objek yang sedang dijaminkan, dengan catatan pada sasat pengambilan ganti rugi oleh debitur harus mendapatkan persetujuan tertulis kreditur.

\section{Kata Kunci : Ganti rugi; Hak Tanggungan; Kepentingan Umum; Konsinyasi}

\section{PENDAHULUAN}

Salah satu tahapan untuk daapt menjadi negara maju adalah telah dimulainya pembangunan nasional berbasis negara dan rakyat (state based devolepment) yang ditunjukan telah tersedianya infrastruktur negara dalam segala aspek khususnya dalam bidang transportasi, karena dengan kemudahan transportasi baik melalui udara, laut maupun darat, secara tidak langsung akan dapat menumbuhkan perekonomian nasioanal (driven factor) dengan kemudahan masyarakat dalam menjalankan transaksitransaksi bisnis yang dapat dikembangkan ke segala penjuru daerah ataupun luar negri sehingga pembangunan infrastruktur dapat memiliki multiplier effect ekonomi yang besar dan signifikan.

Komitmen ataupun kewajiban dari pembangunan infrastruktur oleh negara sebagai penyelenggara dapat dilihat dalam Pembukaan Undang-Undang Dasar 1945 (UUD 45) yang menyatakan :

"Kemudian daripada itu untuk membentuk suatu pemerintah negara Indonesia yang melindungi segenap bangsa Indonesia dan seluruh tumpah darah Indonesia dan untuk memajukan kesejahteraan umum, mencerdaskan kehidupan bangsa, dan ikut melaksanakan ketertiban dunia yang berdasarkan kemerdekaan, perdamaian abadi dan keadilan sosial"

Ditambah lagi di dalam Pasal 34 UUD "Negara bertanggung jawab atas penyediaan fasilitas pelayanan kesehatan dan fasilitas pelayanan umum yang layak" sehingga penulis berpendapat bahwa harus telah timbul tanggung jawab negara sebagai bentuk pelayanannya terhadap warga negara, dalam hal membangun fasilitas umum, baik secara pelayanan (public service) ataupun penyediaan berbagai fasilitas yang diperlukan oleh masyarakat.

Pembangunan Infrastrukutr demi kepentingan umum, tentu tidak semudah seperti membalikan telapak tangan, persiapan tidak hanyaberpacu kepada Sumber Daya Manusia (SDM), keuangan dan perencanaan, namun persiapan pembangunan infrastruktur juga harus dapat mempertimbangkan hadirnya pihak ketiga, terutama pihak ketiga yang memiliki lahan atas alas hak milik yang berbenturan dengan rancangan pembangunan infrastrukutr demi kepentingan umum.

Hadirnya Peraturan Presiden (Perpres) Nomor 3 Tahun 2016 bertujuan untuk mempercepat pelaksanaan proyek strategis nasional guna memenuhi kebutuhan dasar dan meningkatkan kesejahteraan masyarakat, dengan melakukan upaya simplikasi dan kemudahan perizinan dan nonperizinan, penyelesaian tata ruang dan kepastian penyediaan lahan, pemberian jaminan atas risiko perubahan kebijakan Pemerintah, penugasan kepada BUMN, percepatan pengadaan barang/jasa Pemerintah, pemberian diskresi dalam penyelesaian hambatan dan perlindungan hukum bagi aparatur pelaksana proyek strategis nasional, ${ }^{1}$

\footnotetext{
${ }^{1}$ Muhamad Zulfikar Ali, "Komitmen Pemerintah Dalam Penyediaan Infrastruktur: Perpres Nomor 3 Tahun 2016 dan Inpres Nomor 1 Tahun 2016?", https://setkab.go.id/komitmen-pemerintah-dalam-penyediaan-infrastruktur-per-
} 
Sedangkan dalam Instruksi Presiden (Inpres) Nomor 1 Tahun 2016, intinya memberikan instruksi kepada stakeholder terkait untuk mengambil langkah-langkah yang diperlukan untuk melakukan dan/atau memberikan dukungan percepatan pelaksanaan Proyek Strategis Nasional (PSN), yang mencakup penyiapan PSN, pengadaan lahan/tanah PSN, pendanaan PSN, perizinan dan nonperizinan PSN, pelaksanaan pembangunan fisik PSN, pengawasan dan pengendalian PSN, pemberian pertimbangan hukum dalam pelaksanaan PSN, dan/atau mitigasi risiko hukum dan non hukum dalam pelaksanaan PSN. ${ }^{2}$

Masa pemerintahan Presiden Joko Widodo menyuguhkan berbagai pembangunan infrastruktur. Berdasarkan Perpres Nomor 58 Tahun 2017 tentang Percepatan Pelaksanaan Proyek Strategis Nasional, tercatat ada 248 proyek infrastruktur strategis nasional di berbagai wilayah Indonesia mulai dari jalan tol, stasiun kereta api, bandara, pelabuhan, rusun, kilang minyak, Terminal LPG, SPAM, bendungan dan irigasi, peningkatan jangkauan broadband, techno park, Kawasan Ekonomi Khusus, smalter, dan pembangkit listrik. ${ }^{3}$

Dengan banyaknya pembangunan infrastruktur tentunya diperlukan lahan yang cukup luas, sehingga apabila pemerintah tidak mampu menyiapakan lahan terutama tempat yang strategis, pemerintah harus mendapatkan lahan lainnya dengan cara membeli beberapa lahan milik perorangan sebagaimana diamanatkan oleh UndangUndang Republik Indonesia Nomor 2 Tahun 2012 Tentang Pengadaan Tanah Bagi Pembangunan Untuk Kepentingan Umum (UU No. 2 tahun 2012) sebagai mana pada point b menimbang "bahwa untuk menjamin terselenggaranya pembangunan untuk kepentingan umum, diperlukan tanah yang pengadaannya dilaksanakan dengan mengedepankan prinsip kemanusiaan, demokratis, dan adil".

Lebih lanjut lagi didalam Pasal 1 ayat 2 UU No. 2 tahun 2012 Pengadaan Tanah, yaitu kegiatan menyediakan tanah dengan cara memberi ganti kerugian yang layak dan adil kepada pihak yang berhak, dengan ketentuan apabila dalam suatu hal pembukaan lahan untuk membangun proyek infrastruktur demi kepentingan bersama, pemerintah dapat membeli objek tanah milik warga Negara dengan cara ganti rugi yang layak dan adil kepada pihak yang berhak.

Sehingga upaya pemerintah dalam membangung infrastruktur dengan tujuan kepentingan umum apabila terkendala dengan tidak tersedianya lahan kosong yang dimilik oleh negara, dapat ditempuh dengan cara membeli objek tanah yang dimiliki oleh warga negara dengan penggantian yang layak dan adil.

Berdasarkan latar belakang sebagaimana yang telah disebutkan dalam tulisan ini, maka terdapat beberapa hal yang dapat dirumuskan dalam permasalahan yang akan dibahas dalam tulisan ini, yaitu? 1) Bagaimana penerapan konsinyasi terhadap pembebasan tanah untuk kepentingan umum ? 2) Bagaimanakah penyelesaian ganti rugi apabila objek tanah sedang dijaminkan melalui Hak Tanggungan?

Penelitian ini menggunakan metode penelitian hukum normatif, dimana penelitian menitik beratkan pada hukum yuridis normatif dengan melihat ketentuan peraturan perundang-undangan yang menjelaskan tentang wewenang Pengadilan Negeri dalam menerima penitipan uang dalam hal Undang-Undang Nomor 2 Tahun 2012 Tentang

pres-nomor-3-tahun-2016-dan-inpres-nomor-1-tahun-2016/, di akses pada tanggal 10 April 2019

${ }^{2}$ Ibid

3 Agung Hermansyah, "Pembangunan Infrastruktur dan Partisipasi Masyarakat", https://news.detik.com/ kolom/d-4021236/pembangunan-infrastruktur-dan-partisipasi-masyarakat, di akases tanggal 10 april 2019 
Pengadaan Tanah Bagi Pembangunan Untuk Kepentingan Umum dan Penerima pembayaran hutang berdasarkan Kitab Undang-Undang Hukum Perdata. Penelitian ini dilakukan dengan cara meneliti bahan hukum primer, bahan hukum sekunder dan bahan hukum tersier.

\section{PEMBAHASAN}

\section{Pengertian dan Dasar Hukum Konsinyasi serta Hak Tanggungan}

Konsinyasi berasal dari Bahasa Belanda yaitu dari kata CONSIGNATIE yang berarti "Penitipan uang atau barang pada pengadilan guna pembayaran satu utang. Penawaran pembayaran yang disusul dengan penitipan pada pengadilan membebaskan debitur asal dilakukan dengan cara-cara yang sah menurut undang-undang". Berdasarkan pengertian tersebut, tampak bahwa konsinyasi di dahului dengan penawaran pembayaran lalu disusul dengan penitipan uang atau barang pada pengadilan. ${ }^{4}$

Dalam kamus besar Bahasa Indonesia, istilah konsinyasi diartikan sebagai kegiatan penitipan barang dagangan kepada agen atau orang untuk dijualkan dengan pembayaran kemudian (jual titipan). ${ }^{5}$ Utoyo Widayat memberikan pengertian yang lebih lengkap mengenai penjualan konsinyasi, yaitu pengiriman atau penitipan barang dari pemilik kepada pihak lain yang bertindak sebagai agen penjualan dengan memberikan komisi. ${ }^{6}$

Konsinyasi dalam Pasal 1404 KUH Perdata menyatakan "jika si berpiutang menolak pembayaran, maka si berhutang dapat melakukan penawaran pembayaran tunai apa yang diutangkan, dan jika si berpiutang menolaknya, menitipkan uang atau barangnya kepada pengadilan. Penawaran yang sedemikian, diikuti dengan penitipan, membebaskan si berhutang dan berlaku baginya sebagai pembayaran, asal penawaran itu telah dilakukan dengan cara menurut undangundang sedangkan apa yang dititipkan secara itu tetap atas tanggungan si berpiutang."

Bahkan di dalam Pasal 17 ayat (2) Keppres No.55/Tahun 1993 penerapan konsinyasi dapat ditemukan dengan menyebutkan bahwa apabila dalam hal tanah, bangunan, tanaman atau benda yang berkaitan dengan tanah yang dimiliki bersama-sama oleh beberapa orang, sedangkan satu atau beberapa orang dari mereka tidak dapat ditemukan, maka ganti rugi yang menjadi hak orang yang tidak dapat diketemukan tersebut dikonsinyasikan di Pengadilan Negeri setempat oleh instansi pemerintah yang memerlukan tanah.

Konsinyasi yang dikenal di dalam Keppres Nomor 55 Tahun 1993 hanyalah untuk keperluan penyampaian ganti rugi yang telah disepakati, akan tetapi orang yang bersangkutan tidak diketemukan. Berdasarkan ruang lingkup Keppres Nomor 55 Tahun 1993 jelas diketahui bahwa peraturan pengadaan tanah ini hanya berlaku bagi pengadaan tanah yang dilakukan oleh Instansi Pemerintah untuk kepentingan umum. Oleh karena itu konsinyasi hanya bisa diterapkan untuk pembayaran ganti rugi untuk pengadaan tanah dilakukan oleh Instansi Pemerintah untuk kepentingan umum, dengan catatan memang telah ada kesepakatan diantara kedua belah pihak yang membutuhkan

\footnotetext{
${ }^{4}$ Naffi, "Bagaimana Konsinyasi Menurut Pasal 1404 - 1412 Kuh Perdata”, https://badilag.mahkamahagung.go.id/artikel/ publikasi/artikel/bagaimana-konsinyasi-menurut-pasal-1404-1412-kuh-perdata-oleh-naffi-s-ag-m-h-3-7 , diakses pada hari sabtu 13 April 2019

${ }^{5}$ Departemen Pendidikan Nasional, 2008, Kamus Besar Bahasa Indonesia Pusat Bahasa Edisi Keempat, cetakan keempat, Gramedia Pusat Utama, Jakarta, hlm. 125

${ }^{6}$ Utoyo Widayat, 1999, Akuntansi Keuangan Lanjutan : Ikhtisar Teori Dan Soal, edisi revisi, LPFE UI, Jakarta, hlm. 125
} 
tanah dan pemegang hak atas tanah dan pemilik bangunan, tanaman dan/atau bendabenda yang ada di atas tanah tersebut. ${ }^{7}$

Dasar Hukum Penitipan uang ganti rugi di Pengadilan Negeri juga termuat dalam Pasal 10 ayat 2 Peraturan Presiden Nomor 65 Tahun 2006, yang menyatakan Apabila setelah diadakan musyawarah sebagaimana dimaksud pada ayat (1) tidak tercapai kata sepakat, panitia pengadaan tanah menetapkan besarnya ganti rugi sebagaimana dimaksud dalam Pasal 13 huruf a dan menitipkan ganti rugi uang kepada pengadilan negeri yang wilayah hukumnya meliputi lokasi tanah yang bersangkutan.

Undang-Undang Republik Indonesia Nomor 2 Tahun 2012 Tentang Pengadaan Tanah Bagi Pembangunan Untuk Kepentingan Umum, Pasal 48 menyebutkan Dalam hal Pihak yang Berhak menolak bentuk dan/atau besarnya Ganti Kerugian berdasarkan hasil musyawarah sebagaimana dimaksud dalam Pasal 37, atau putusan pengadilan negeri/ Mahkamah Agung sebagaimana dimaksud dalam Pasal 38, Ganti Kerugian dititipkan di pengadilan negeri setempat.

Bahkan Peraturan Kepala Badan Pertanahan Nasional Republik Indonesia Nomor 3 Tahun 2007 Tentang Ketentuan Pelaksanaan Peraturan Presiden Nomor 36 Tahun 2005 Tentang Pengadaan Tanah Bagi Pelaksanaan Pembangunan Untuk Kepentingan Umum Sebagaimana Telah Diubah Dengan Peraturan Presiden Nomor 65 Tahun 2006 Tentang Perubahan Atas Peraturan Presiden Nomor 36 Tahun 2005 Tentang Pengadaan Tanah Bagi Pelaksanaan Pembangunan Untuk Kepentingan Umum, Pasal 48 Panitia Pengadaan Tanah Kabupaten/Kota memerintahkan kepada instansi pemerintah yang memerlukan tanah untuk menitipkan ganti rugi uang ke pengadilan negeri yang wilayah hukumnya meliputi letak tanah bagi pelaksanaan pembangunan dalam hal : a) yang berhak atas ganti rugi sebagaimana dimaksud dalam Pasal 43 ayat (1) tidak diketahui keberadaannya; b) tanah, bangunan, tanaman dan/atau benda-benda lain yang berkaitan dengan tanah, sedang menjadi obyek perkara di pengadilan dan belum memperoleh putusan pengadilan yang mempunyai kekuatan hukum tetap; c) masih dipersengketakan kepemilikannya dan belum ada kesepakatan penyelesaian dari para pihak; dan d) tanah, bangunan, tanaman dan/atau benda-benda lain yang berkaitan dengan tanah, sedang diletakkan sita oleh pihak yang berwenang.

Mengenai Hak Tanggungan, sumber dari terbentuknya suatu Tanggungan berawal dari perikatan yang dibuat dan disetujui oleh para pihak. Hukum perikatan diatur dalam Buku ke III KUHPerdata. Definisi mengenai perikatan tidak diatur didalamnya, tetapi definisi ini diberikan oleh ilmu pengetahuan, yaitu suatu hubungan hukum dalam lapangan harta kekayaan antara dua orang atau lebih dimana pihak yang satu berhak atas sesuatu dan pihak lain berkewajiban atas sesuatu. ${ }^{8}$

Ketentuan tersebut menunjukan bahwa para pihak diberi kebebasan untuk melakukan sesuatu dengan pihak lainnya sepanjang hal tersebut disepakati dan menimbulkan timbal balik yang saling menguntungkan sepanjang hal tersebut tidak bertentangan dengan undang-undang, kesusilaan dan ketertiban umumu, seperti dalam hal nya jaminan yang dibebankan Hak Tanggungan.

Kebebasan berkontrak inilah yang kemudian menjadikan lembaga jaminan seperti Hak Tanggungan membentuk sendiri akta atau perjanjian yang dilakukan antara pemberi Hak Tanggungan dengan penerima Hak Tanggungan. Perjanjian yang dilakukan antara pemberi Hak Tanggungan dengan penerima Hak Tanggungan ini kemudian dituangkan

\footnotetext{
${ }^{7}$ Tami Rusli, 2018, “Analisis Pelaksanaan Konsinyasi Ganti Rugi Pada Pengadaan Tanah,” hlm. 20, Jurnal Keadilan Progresif Volume 9 Nomor 1, http://jurnal.ubl.ac.id/index.php/KP/article/view/1009/1062

${ }_{8}^{8}$ Puwahid Patrik, 1994, Dasar-Dasar Hukum Perikatan ( Perikatan Yang Lahir Dari Perjanjian Dan Undang-Undang), CV. Mandar Maju, Bandung, hlm. 2
} 
kedalam suatu akta yang dibuat dihadapan notaris kemudian didaftakan ke Kantor Pertanahan. ${ }^{9}$

Dimana istilah jaminan merupakan secara umum cara-cara kreditur menjamin dipenuhinya tagihan, disamping pertanggungan jawab umum debitur terhadap barang-barangnya, fungsi utamanya adalah untuk memperkecil, mengurangi resiko yang dapat dialami oleh kreditur atau bank sebagai penyalur kredit atau dengan kata lain fungsinya adalah sebagai sarana perlindungan bagi keamanan kreditur, yaitu mengenai kepastian pelunasan hutang oleh debitur atau penjamin debitur, kepastian debitur dalam melaksanakan segala kewajiban prestasinya. ${ }^{10}$ Berdasarkan peraturan perundang undangan yang berlaku maka pengikatan hak atas tanah tersebut wajib dilakukan melalui lembaga Hak Tanggungan yang dibuat dengan Akta Pemberian Hak Tanggungan (APHT). Adanya pengikatan jaminan melalui hak tanggungan ini memberikan kepastian hukum bagi bank dan pihak-pihak lain yang berkepentingan. ${ }^{11}$

Istilah Hak Tanggungan diambil dari istilah lembaga jaminan di dalam hukum adat. Di dalam hukum Adat istilah Hak Tanggungan dikenal di daerah Jawa Barat, juga dibeberapa daerah di Jawa Tengah atau Jawa Timur dan dikenal juga dengan istilah jonggolan atau istilah ajeran merupakan lembaga jaminan dalam hukum adat yang obyeknya biasanya tanah atau rumah. ${ }^{12}$

Undang-Undang Republik Indonesia Nomor 4 Tahun 1996 Tentang Hak Tanggungan Atas Tanah Beserta Benda-Benda Yang Berkaitan Dengan Tanah mendefinisikan Hak Tanggungan adalah adalah hak jaminan yang dibebankan pada hak atas tanah sebagaimana dimaksud dalam Undang-Undang Nomor 5 Tahun 1960 tentang Peraturan Dasar Pokok-Pokok Agraria, berikut atau tidak berikutbenda-benda lain yang merupakan satu kesatuan dengan tanah itu, untuk pelunasan utang tertentu, yang memberikan kedudukan yang diutamakan kepada kreditor tertentu terhadap kreditor-kreditor lain. Berdasarkan Undang-Undang Nomor 4 Tahun 1996, Hak Tanggungan memeiliki beberepa sifat dan asas, yaitu : 1) Hak Tanggungan mempunyai sifat hak didahulukan, (droit de preference) sebagaimana dalam Pasal 1 angka 1 Undang UndangNomor 4 Tahun 1996. 2) Hak Tanggungan mempunyai sifat tidak dapat dibagi-bagi sebagaimana dalam Pasal 2 ayat 1 Undang UndangNomor 4 Tahun 1996. 3) Hak Tanggungan dapat saja dibebankan bukan saja pada hak atas tanah yang menjadi objek Hak Tanggungan, tetapi juga berikut bangunan, tanaman, dan hasil karya yang merupakan satu kesatuan dengan tanah tersebut ${ }^{13}$. 4) Hak Tanggungan mempunyai sifat Accessoir, sebagaimana tercantum dalam Undang UndangNomor 4 Tahun 1996 angka 8, Pasal 1o ayat (1), dan Pasal 18 ayat (1). 5) Hak Tanggungan mempunyai sifat dapat diberikan dengan lebih dari satu kreditur (hutang), sebagaimana dalam Pasal 3 ayat (2) Undang UndangNomor 4 Tahun 1996. 6) Hak Tanggungan mempunyai sifat tetap mengikuti objeknya dalam tangan siapapun, sebagaimana dalam Pasal 7 Undang UndangNomor 4 Tahun 1996. 7) Hak Tanggungan mempunyai sifat dapat beralih dan dialihkan. Hak Tanggungan

\footnotetext{
${ }^{9}$ Denico Doly, 2011, “Aspek Hukum Hak Tanggungan Dalam Pelaksanaan Roya,” Negara Hukum Vol. 2, No. 1, hlm. 109, https://jurnal.dpr.go.id/index.php/hukum/article/view/185

${ }^{10}$ Ariel Doni Dharmawan, 2018, "Kekuatan Hukum Sertifikat Hak Tanggungan Dalam Hal Musnahnya Obyek Hak Tanggungan Karena Bencana Alam Di Kabupaten Grobogan,” Jurnal Akta Vol 5 No 1, hlm. 173, http://jurnal. unissula.ac.id/index.php/akta/article/view/2545

${ }^{11}$ Freddy Putera Husein, 2018, "Kepastian Hukum Penerapan Jangka Waktu Perpanjangan Hak Guna Bangunan Yang Berakhir Masa Berlakunya Sebagai Obyek Hak Tanggungan Sebelum Perjanjian Pokok Berakhir Dikaitkan Dengan Peraturan Perundang-Undangan Yang Berlaku", Acta Diurnal Jurnal Hukum Kenotariatan dan ke-PPAT-an, ISSN: 2614-3542 EISSN: 2614-3550, Volume 2, Nomor 1, hlm. 95, http://jurnal.fh.unpad.ac.id/index.php/jad/article/view/162

${ }^{12}$ Rachmadi Usman, 2008, Hukum Jaminan Keperdataan, Sinar Grafika, Jakarta, hlm. 329

${ }^{13}$ Sutarno, 2003, Aspek-Aspek Hukum Perkreditan Pada Bank, Alfabeta, Bandung, hlm. 26
} 
dapat beralih dan dialihkan sebagaimana diatur dalam Pasal 16 ayat (1) UndangUndang Nomor 4 Tahun 1996. Hak Tanggungan dapat beralih dan dialihkan karena mungkin piutang yang dijaminkan itu dapat beralih dan dialihkan. Ketentuan bahwa Hak Tanggungan dapat beralih dan dialihkan yaitu dengan terjadinya peralihan atau perpindahan hak milik atas piutang yang dijamin dengan Hak Tanggungan tersebut atau Hak Tanggungan beralih karena beralihnya perikatan pokok. ${ }^{14}$ 8) Hak Tanggungan memiliki sifat yang mudah dieksekusi, sebagaimana diatur dalam Pasal 6 UndangUndang Nomor 4 Tahun 1996.

Untuk pelaksanaan Hak Tanggungan, ada beberapa peraturan perundang-undangan yang dapat dijadikan dasar hukum, antara lain adalah sebagai berikut ${ }^{15}$ :

1. Undang-Undang Nomor 5 Tahun 1960 tentang Peraturan Dasar Pokok-pokok Agraria (UUPA).Haliniterdapatdalam Pasal25ketentuanterkaitHakMilik, Pasal33ketentuan terkait Hak Guna Usaha, Pasal 39 ketentuan terkait Hak Guna Bangunan dan Pasal 51 ketentuan terkait Hak Tanggungan yang dapat dibebankan pada hak milik, hak guna usaha, hak guna bangunan tersebut, diatur dengan undang-undang lain.

2. Undang-Undang Nomor 4 Tahun 1996, tentang Hak Tanggungan Atas Tanah beserta Bendabenda yang Berkaitan dengan Tanah (UU Hak Tanggungan).

3. Peraturan Pemerintah Nomor 24 Tahun 1997 tentang Pendaftaran Tanah.

4. PeraturanPemerintahNomor37Tahun1998tentangPeraturanJabatanPejabatPembuat Akta Tanah.

5. Peraturan Pemerintah Nomor 24 Tahun 2016 tentang Perubahan atas Peraturan Pemerintah Nomor 37 Tahun 1998 tentang Peraturan Jabatan Pejabat Pembuat Akta Tanah.

6. Peraturan Menteri Negara Agraria/Kepala Badan Pertanahan Nasional Nomor 4 Tahun 1996 tentang Penetapan Batas Waktu Penggunaan Surat Kuasa Membebankan Hak Tanggungan Untuk Menjamin Pelunasan Kredit-Kredit Tertentu.

7. Peraturan Menteri Negara Agraria/Kepala Badan Pertanahan Nasinal Nomor 5 Tahun 1996 tentang Pendaftaran Hak Tanggungan.

8. Peraturan Kepala Badan Pertanahan Nasional Nomor 1 Tahun 2010 tentang Standar Pelayanan dan Pengaturan Pertanahan.

9. Peraturan Kepala Badan Pertanahan Nasional Nomor 8 Tahun 2012 tentang Perubahan atas Peraturan Menteri Negara Agraria/Kepala Badan Pertanahan Nasional Nomor 3 Tahun 1997.

10. Peraturan Kepala Badan Pertanahan Nasional Nomor 2 Tahun 2013 tentang Pelimpahan Kewenangan Pemberian Hak Atas Tanah.

\section{Prosedur beralihnya kepemilikan hak milik atas tanah dan benda yang ada dia- tasnya melalui permohonan konsinyasi oleh pemerintah}

Kepmilikan terhadap tanah merupakan hak yang dimiliki oleh setiap warga negara, hal tersebut tercermin dalam Pasal 28 D Ayat (1) UUD yang menyebutkan "Setiap orang berhak atas pengakuan, jaminan, perlindungan dan kepastian hukum yang adli serta perlakuan yang sama dihadapan hukum", dan dikung juga dengan keterhadiran pemerintah dalam Pasal 33 ayat (3) UUD 45 yang menegaskan "bahwa bumi, air dan kekayaan alam yang terkandung di dalamnya dikuasi oleh negara untuk dipergunakan bagi sebesar-besarnya kemakmuran rakyat" yang teraplikasikan dalam UU PA, maupun

\footnotetext{
${ }^{14}$ Kartini Muljadi dan Gunawan Widjaja, 2005, Hak Tanggungan, Prenada Media, Jakarta, hlm. 105

${ }^{15}$ Abdul Kholiq Imron, 2017, "Pembebanan Hak Tanggungan Terhadap Objek Tanah Yang Belum Terdaftar Bersamaan Permohonan Pendaftaran Tanah Pertama Kali”, Jurnal Repertorium Volume IV No. 2, hlm 8-9, https://jurnal. uns.ac.id/repertorium/article/view/18232
} 
peraturan lainnya sampai kepada Instansi yang bersangkutan seperti Badan Pertanahan Negara (BPN), dimana peraturan-peraturan tersebut secara garis beras untuk dapat menyelenggarakan memberikan jaminan dan kepastian hukum terhadap penguasaan dan penggunaan tanah dengan cara yang tepat, sesuai tatanan hukum, tidak melanggar kepentingan umum bahkan mempunyai sosial hak atas tanah atau dikenal dengan istilah the social function of property.

Duguit berpendapat bahwa properti atau dikenal dengan kepemilikan hak atas tanah bukan merupakan hak tapi lebih dari itu merupakan fungsi sosial. Pemilik memiliki kewajiban sehubungan dengan fungsi sosialnya sehingga tidak bisa hanya melakukan apa yang dia inginkan saja atas properti miliknya. Dijelaskan lagi bahwa pemilik wajib menjadikan tanah hak miliknya menjadi produktif dan diletakkan demi pelayanan untuk masyarakat melalui kegiatan ekonomi. Ide fungsi sosial dari properti atau lebih dikenal dengan fungsi sosial hak atas tanah berdasarkan deskripsi realitas sosial mengakui solidaritas sebagai salah satu fondasi utamanya. Akibatnya, negara harus melindungi tanah hanya jika memenuhi fungsi sosialnya. Ketika pemilik tidak bertindak dengan cara yang konsisten dengan kewajibannya, negara harus melakukan intervensi untuk mendorong atau menghukumnya. ${ }^{16}$

Sehingga kepemilikan suatu objek tanah tidak hanya melihat kepada kepentingan pribadi dari pemilik tersebut, namun objek tanah yang dikuasi haruslah dapat memiliki manfaat baik untuk kepentingan sendiri maupun untuk kepentingan umum apalagi negara dalam hal pembangunan infrastruktur yang memerlukan pengadaan tanah yang tidak sedikit.

Jazim Hamidi memberikan indikator atau unsur-unsur yang termuat di dalam asas kepentingan umum yaitu, untuk kepentingan nasional, bangsa, dan negara, kepentingan pembangunan, kepentingan masyarakat, dan ada dasar peraturan perundangundangannya. ${ }^{17}$

Pengadaan Tanah untuk pembangunan dilaksanakan dengan menghormati (melindungi) hak atas tanah masyarakat. Sebelum dilakukan pengadaan tanah untuk pembangunan, dibentuk panitia pengadaan tanah yang mempunyai tugas mengadakan penelitian dan inventarisasi atas tanah, mengadakan penelitian status hukum tanah, menaksir dan mengusulkan besarnya ganti rugi, memberikan penyuluhan kepada pemegang hak atas tanah, mengadakan perundingan dengan pemegang hak atas tanah, menyaksikan pelaksanaan penyerahan uang ganti rugi dan membuat berita acara penyerahan hak atas tanah. ${ }^{18}$

Dalam hal pemilik tanah tidak menerima ganti rugi yang diberikan oleh pemerintah, maka pemerintah dapat mengajukan permohonan konsinyasi terhadap Pengadilan. Namun sebelum mengajukan permohonan konsinyasi, perlu dipahami terlebih dahulu bahwa konsinyasi meliputi dua tahapan, yaitu adanya Penawaran yang disusuli dengan penitipan, adapun syarat sah penawaran yaitu terdapat pada Pasal 1405 KUH Perdata, yaitu : 1) Penawaran harus dilakukan kepada kreditur atau kuasanya. 2) Dilakukan oleh orang yang berwenang melakukan pembayaran. 3) Penawarah harus meliputi :a. Seluruh uang pokok, b. Bunga, c. Biaya yang telah ditetapkan, d. Uang untuk biaya yang

${ }^{16}$ Triana Rejekiningsih, 2016, “Asas Fungsi Sosial Hak Atas Tanah Pada Negara Hukum (Suatu Tinjauan Dari Teori, Yuridis Dan Penerapannya Di Indonesia)", Yustisia. Vol. 5 No. 2, hlm. 305, https://jurnal.uns.ac.id/yustisia/ article/view/8744

${ }^{17}$ Jazim Hamidi, 2015, Makalah External Review atas Penjelasan Hukum AUPB, Jakarta, hlm. 5. Lebih lengkapnya lihat: Jazim Hamidi, 1999, Penerapan AAUPPL Di Lingkungan Peradilan Administrasi Negara, Citra Aditya Bakti, Bandung

${ }^{18}$ Effendi Perangin, 1994, Hukum Agraria Di Indonesia Suatu Telaah Dari Sudut Pandang Praktisi Hukum, Rajawali Pers, Jakarta, hlm. 52 
belum ditetapkan. Dengan diajukannya penawaran, maka pemohon dianggap sudah memiliki itikad baik, sehingga apabila penawaran tersebut ditolak, maka pemohon dapat mengajukan penitipan melalui Pengadilan dengan syarat yang tertuang dalam Pasal 1406 KUH Perdata

Berdasarkan Peraturan Mahkamah Agung Republik Indonesia Nomor 3 Tahun 2016 Tentang Tata Cara Pengajuan Keberatan Dan Penitipan Ganti Kerugian Ke Pengadilan Negeri Dalam Pengadaan Tanah Bagi Pembangunan Untuk Kepentingan Umum, peraturan tersebut mengatur mengenai bagaimana Pemohon mengajukan permohonannya ke pengadilan dalam hal Pentipan ganti kerugian, sebagaiman tercantum dalam Pasal 24, yaitu

(1)Instansi yang memerlukan tanah dapat mengajukan permohonan Penitipan Ganti Kerugian kepada Pengadilan dalam hal memenuhi satu atau lebih keadaan berikut ini:

a. pihak yang berhak menolak bentuk dan/atau besarnya Ganti Kerugian berdasarkan hasil Musyawarah Penetapan Ganti Kerugian tetapi tidak mengajukan Keberatan ke Pengadilan;

b. pihak yang berhak menolak bentuk dan/atau besarnya Ganti Kerugian berdasarkan putusan Pengadilan yang telah memperoleh kekuatan hukum tetap;

c. pihak yang berhak tidak diketahui keberadaannya;

d. objek pengadaan tanah yang akan diberikan Ganti Kerugian: 1) sedang menjadiobjek perkara di pengadilan; 2) masih dipersengketakan kepemilikannya;3) diletakkan sita oleh pejabat yang berwenang; 4) menjadi jaminan di bank.

(2)Bentuk Ganti Kerugian yang dapat dititipkan di Pengadilan sebagaimana dimaksud pada ayat (1) berupa uang dalam mata uang rupiah.

Permohonan Penitipan Ganti Rugi tersebut diajukan secara tertulis dalam Bahas Indonesia oleh pemohon dengan melengkapaiidentitas pemohon dan termohon dengan menguraikan alasan yang menjadi dasar Permohonan Penitipan Ganti Kerugian, yang selanjutnya diperiksa oleh Panitera dan memberikan Tanda Terima Berkas setelah dilakukan panjar biaya atas permohonan tersebut.

Setelah Pengadilan memeriksa permohonan yang diajukan, apabila permohonan dapat diterima dengan berabagai macam pemeriksaan ataupun serangkaian sidang, maka Ketua Pengadilan menerbitkan penetapan dengan amar: a) mengabulkan permohonan Pemohon; b) menyatakan sah dan menerima Penitipan Ganti Kerugian dengan menyebutkan jumlah besaran ganti kerugian, data fisik dan data yuridis bidang tanah dan/atau bangunan serta pihak yang berhak menerima; c) memerintahkan paniterauntukmelakukanpenyimpananuangGantiKerugiandanmemberitahukannya kepada Termohon; d) membebankan biaya perkara kepada Pemohon.

Panitera membuat berita acara penyimpanan penitipan uang Ganti Kerugian yang ditandatangani oleh Panitera, Pemohon dan 2 (dua) orang saksi dengan menyebutkan jumlah danrinciannyauntukdisimpan dalamkas KepaniteraanPengadilansebagaiuang penitipanGantiKerugian.Salinanberitaacarasebagaimanadimaksuddisampaikan pula kepada Pemohon dan Termohon. Ketidakhadiran Termohon dalam penyerahan uang Ganti Kerugian tidak menghalangi dilakukannya penyimpanan uang Ganti Kerugian.

Lebih lanjut Pasal 43 Undang-Undang Nomor 2 Tahun 2012 tentang Pengadaan Tanah Bagi Pembangunan untuk Kepentingan Umum menyatakan "Pada saat pelaksanaan pemberian Ganti Kerugian dan Pelepasan Hak sebagaimana dimaksud dalam Pasal 41 ayat (2) huruf a telah dilaksanakan atau pemberian Ganti Kerugian sudah dititipkan di pengadilan negeri sebagaimana dimaksud dalam Pasal 42 ayat (1), kepemilikan atau Hak Atas Tanah dari Pihak yang Berhak menjadi hapus dan alat 
bukti haknya dinyatakan tidak berlaku dan tanahnya menjadi tanah yang dikuasai langsung oleh negara."

Bahkan, didalam Undang-Undang Republik Indonesia Nomor 20 Tahun 1961 Tentang Pencabutan Hak-Hak Atas Tanah DanBenda-Benda Yang Ada Di Atasnya (UU PHATB), Presiden demikepentinganumumdiberikanwewenanguntuk mencabuthakhak atas tanah dan benda-benda yang ada dia atasnya, hal tersebut tertuang dalam Pasal 1 UU PHATB, "Untuk kepentingan umum, termasuk kepentingan Bangsa dan Negara serta kepentingan bersama dari rakyat, demikian pula kepentingan pembangunan, maka Presiden dalam keadaan yang memaksa setelah mendengar Menteri Agraria, Menteri Kehakiman dan Menteri yang bersangkutan dapat mencabut hak-hak atas tanah dan benda-benda yang ada di atasnya.

\section{Penerapan Ganti Rugi Terhadap Objek Tanah Yang Sedang Dalam Jaminan}

Apabila, tahapan-tahapan penawaran dan permohonan konsinyasi sudah dilakukan sebagaimana yang telah disampaikan dan telah memeliki penetapan pengadilan yang diikuti beralihnya objek kepemilikan hak milik, maka pemilik objek lahan sebelumnya dapat mengambil ganti kerugian tersebut di pengadilan sebagaiman di atur dalam Peraturan Mahkamah Agung Republik Indonesia Nomor 3 Tahun 2016 Tentang Tata Cara Pengajuan Keberatan Dan Penitipan Ganti Kerugian Ke Pengadilan Negeri Dalam Pengadaan Tanah Bagi Pembangunan Untuk Kepentingan Umum, terutama pada Pasal 30 adalah sebagai berikut :

Dalam hal pihak yang berhak menolak bentuk dan/atau besarnya Ganti Kerugian berdasarkan Musyawarah Penetapan Ganti Kerugian tetapi tidak mengajukan keberatan ke pengadilan negeri atau menolak Ganti Kerugian berdasarkan putusan Pengadilan yang telah memperoleh kekuatan hukum tetap, Ganti Kerugian dapat diambil di kepaniteraan Pengadilan dalam waktu yang dikehendaki oleh pihak yang berhak disertai dengan surat pengantar dari Ketua Pelaksana Pengadaan Tanah.

Pihak yang berhak dalam Pasal 30 Perma No. 3 tahun 2016 tersebut adalah, pihak yang menguasi objek lahan sebagaimana yang dipermohonkan dan didukung dengan bukti kepemilkan formal (sertipikat) yang mana dalam Pasal 32 Ayat (1) Peraturan Pemerintah No.24 Tahun 1997 disebutkan bahwa: sertifikat merupakan surat tanda bukti yang kuat mengenai data fisik dan data yuridis yang termuat di dalamnya, sepanjang data fisik dan data yuridis tersebut sesuai dengan data yang ada dalam surat ukur dan buku tanah hak yang bersangkutan. Sedangkan dalam Penjelasan pasal 32 Ayat (1) Peraturan Pemerintah No. 24 Tahun 1997 menyatakan bahwa sertifikat merupakan tanda bukti hak yang kuat, dalam arti bahwa selama tidak dapat dibuktikan sebaliknya data fisik dan data yuridis yang tercantum didalamnya harus diterima sebagai data yang benar.

Konsep tersebut menunjukan bahwa dengan adanya bukti kepemilikan telah menunjukan kepastian hukum bagi pihak yang menguasainya, walaupun dalam hal pertanahan Sertipikat Hak Milik bukanlah suatu bukti kepemilikan yang secara mutlak dan tidak terbantahkan milik dari seseorang, melainkan SHM adalah merupakan bukti kepemilikan terkuat yang dapat dimiliki oleh seseorang dalam menunjukan kepemilikan atas suatu objek tanah yang dikuasainya, hal tersebut juga tercantum didalam Pasal 32 Ayat (1) PP No. 24 Tahun 1997 sertifikat merupakan tanda bukti yang kuat selama tidak dapat dibuktikan sebaliknya data fisik dan data yuridis yang tercantum didalamnya diterima sebagai data yang benar, lebih lanjut didalam penjelasan Pasal 20 UUPA yaitu disebutkan sifat-sifat daripada hak milik yang membedekan dengan hakhak lainnya. Hak milik adalah hak yang 'terkuat dan terpenuhi' yang dapat dipunyai 
orang atas tanah. Pemberian sifat ini tidak berarti, bahwa hak itu merupakan hak yang 'mutlak', tak terbatas dan tidak dapat diganggu gugat' sebagai hak eigendom menurut pengertiannya yang asli dulu.

Dalam hal objek tanah menajdi sengketa Pasal 32 Perma No. 3 tahun 2016 menyebutkan Ganti Kerugian diambil oleh pihak yang berhak di kepaniteraan Pengadilan setelah terdapat putusan pengadilan yang telah berkekuatan hukum tetap atau akta perdamaian, disertai dengan surat pengantar dari Ketua Pelaksana Pengadaan Tanah. Pasal 33 Dalam hal objek pengadaan tanah diletakkan sita oleh pejabat yang berwenang, Ganti Kerugian diambil oleh pihak yang berhak di kepaniteraan Pengadilan setelah adanya putusan pengadilan yang telah berkekuatan hukum tetap atau sita telah diangkat, disertai dengan surat pengantar dari Ketua Pelaksana Pengadaan Tanah. Namun apabila objek tersebut sedang dalam jaminan kepada bank, Pasal 34 Perma No. 3 tahun 2016 mengatur, dalam hal objek pengadaan tanah menjadi jaminan di bank, Ganti Kerugian dapat diambil di kepaniteraan Pengadilan setelah adanya persetujuan dari pihak bank, disertai dengan surat pengantar dari Ketua Pelaksana Pengadaan Tanah.

Dengan ketentuan yang ada tersebut maka penerima ganti rugi tidak bisa serta merta mengambil ganti kerugiannya apabila objek tersebut masih dalam jaminan pihak bank, begitu juga pihak bank tidak bisa menerima atau meminta ganti kerugian secara langsung kepada Panitera Pengadilan, karena syarat dari pengambilan tersebut adalah yang berhak dan ditunjukan dengan bukti kepemilikan yaitu sertipikat atas nama penerima hak ganti kerugian, yang mana bank bukan merupakan pemilik objek hanya pemegang jaminan atas suatu kredit yang diajukan oleh debiturnya.

Sehingga diberlakukannya peraturan tersebut dapat menunjukan perlindungan maupun kepastian hukum terhadap proses konsinyasi. Kepastian hukum menurut pendapat Jan Michiel Otto dalam bukunya Adrian Sutendi, bahwa untuk menciptakan kepastian hukum harus memenuhi syarat-syarat sebagai berikut ${ }^{19}$ : (1) Ada aturan hukum yang jelas dan konsisten; (2) Instansi pemerintah menerapkan aturan hukum secara konsisten, tunduk dan taat terhadapnya; (3) Masyarakat menyesuaikan perilaku mereka terhadap aturan hukum tersebut; (4) Hakim-hakim yang mandiri, tidak berpihak dan harus menerapkan aturan hukum secara konsisten serta jeli sewaktu menyelesaikan sengketa hukum; (5) Putusan pengadilan secara konkrit dilaksanakan

\section{SIMPULAN}

Penerapan Konsinyasi dengan tujuan kepentingan umum dapat mengenyampingkan ketentuan lainnya, tertuama perjanjian yang dilakukan secara privat, oleh karenanya pemerintah berdasrkan Peraturan Mahkamah Agung Republik Indonesia Nomor 3 Tahun 2016 Tentang Tata Cara Pengajuan Keberatan Dan Penitipan Ganti Kerugian Ke Pengadilan Negeri Dalam Pengadaan Tanah Bagi Pembangunan Untuk Kepentingan Umum dapat mengajukan permohonan untuk menitipkan ganti rugi tersebut, sehingga berdasarkan hukum, kepemilikan dapat beralih penguasaaanya kepada negara yang diwakili oleh pemerintah dalam membangun infrastruktur.

Jika melihat sifat dan asas dari Hak Tanggungan seharusnya Kreditur dapat didahulukan dalam penerimaan pembayaran, sedangkan disisi lain penerima ganti rugi adalah subjek hukum yang berhak untuk menerima ganti rugi tersebut kepada panitera pengadilan, oleh karenanya untuk melindungi kepentingan para pihak Perma No. 3 tahun 2016 mengatur apabila objek pengadaan tanah masih menjadi jaminan

19 Adrian Sutedi, 2011, Sertifikat Hak Atas Tanah, Sinar Grafika, Jakarta, hlm. 27 
pihak bank, maka pemilik objek pengadaan tanah dalam meminta pencairan ganti rugi haruslah dengan persetujuan pihak bank.

\section{DAFTAR PUSTAKA}

\section{Buku}

Adrian Sutedi, (2011), Sertifikat Hak Atas Tanah, Sinar Grafika, Jakarta.

Effendi Perangin, (1994), Hukum Agraria Di Indonesia Suatu Telaah Dari Sudut Pandang Praktisi Hukum, Rajawali Pers, Jakarta.

Jazim Hamidi, (2015), Makalah External Review atas Penjelasan Hukum AUPB, Jakarta.

Kartini Muljadi dan Gunawan Widjaja, (2005), Hak Tanggungan, Prenada Media, Jakarta.

Departemen Pendidikan Nasional, (2008), Kamus Besar Bahasa Indonesia Pusat Bahasa Edisi Keempat, cetakan keempat, PT Gramedia Pusat Utama, jakarta.

Puwahid Patrik, (1994), Dasar-Dasar Hukum Perikatan ( Perikatan Yang Lahir Dari Perjanjian Dan Undang-Undang), CV. Mandar Maju, Bandung.

Rachmadi Usman, (2008), Hukum Jaminan Keperdataan, Sinar Grafika, Jakarta.

Sutarno, (2003), Aspek-Aspek Hukum Perkreditan Pada Bank, Alfabeta, Bandung.

Utoyo Widayat, (1999), Akuntansi Keuangan Lanjutan : Ikhtisar Teori Dan Soal, LPFE UI, edisi revisi, Jakarta.

\section{Journal dan Karya Ilmiah Lain}

Abdul Kholiq Imron, (2017). "Pembebanan Hak Tanggungan Terhadap Objek Tanah Yang Belum Terdaftar Bersamaan Permohonan Pendaftaran Tanah Pertama Kali," Jurnal Repertorium Volume IV No. 2, https:/jurnal.uns.ac.id/repertorium/ article/view/18232

Ariel Doni Dharmawan, (2018). "Kekuatan Hukum Sertifikat Hak Tanggungan Dalam Hal Musnahnya Obyek Hak Tanggungan Karena Bencana Alam Di Kabupaten Grobogan", Jurnal Akta Vol 5 No 1, http://jurnal.unissula.ac.id/index.php/akta/ article/view/2545

Denico Doly, (2011). "Aspek Hukum Hak Tanggungan Dalam Pelaksanaan Roya," Negara Hukum: Vol. 2, No. 1, https://jurnal.dpr.go.id/index.php/hukum/article/ view/185

Freddy Putera Husein, (2018). "Kepastian Hukum Penerapan Jangka Waktu Perpanjangan Hak Guna Bangunan Yang Berakhir Masa Berlakunya Sebagai Obyek Hak Tanggungan Sebelum Perjanjian Pokok Berakhir Dikaitkan Dengan Peraturan Perundang-Undangan Yang Berlaku," Acta Diurnal Jurnal Hukum Kenotariatan dan ke-PPAT-an, ISSN: 2614-3542 EISSN: 2614-3550, Volume 2, Nomor 1, http://jurnal.fh.unpad.ac.id/index.php/jad/article/view/162

Naffi, (2015). "Bagaimana Konsinyasi Menurut Pasal 1404 -1412 Kuh Perdata," https:// badilag.mahkamahagung.go.id/artikel/publikasi/artikel/bagaimana-konsinyasimenurut-pasal-1404-1412-kuh-perdata-oleh-naffi-s-ag-m-h-3-7.

Tami Rusli, (2018). "Analisis Pelaksanaan Konsinyasi Ganti Rugi Pada Pengadaan Tanah," Keadilan Progresif Volume 9 Nomor 1, http://jurnal.ubl.ac.id/index.php/ 
KP/article/view/1009/1062

Triana Rejekiningsih, (2016). "Asas Fungsi Sosial Hak Atas Tanah Pada Negara Hukum (Suatu Tinjauan Dari Teori, Yuridis Dan Penerapannya Di Indonesia)," Yustisia. Vol. 5 No. 2, https://jurnal.uns.ac.id/yustisia/article/view/8744

\section{Peraturan Perundang-Undangan}

Undang-Undang Dasar Negara Republik Indonesia Tahun 1945

Kitab Undang-Undang Hukum Perdata

Undang-Undang Nomor 5 Tahun 1960 tentang Peraturan Dasar Pokok-Pokok Agraria (Lembaran Negara Tahun 1960 No. 10 Tambahan Lembaran Negara Nomor 2043)

Undang-Undang Nomor 4 Tahun 1996 Tentang Hak Tanggungan Atas Tanah Beserta Benda-Benda Yang Berkaitan Dengan Tanah (Lembaran Negara Tahun 1996 Nomor 42, Tambahan Lembaran Negara Nomor 3632)

Undang-Undang Nomor 2 Tahun 2012 Tentang Pengadaan Tanah Bagi Pembangunan Untuk Kepentingan Umum (Lembaran Negara Tahun 2012 Nomor 22, Tambahan Lembaran Negara Nomor 5280)

Peraturan Mahkamah Agung Republik Indonesia Nomor 3 Tahun 2016 Tentang Tata Cara Pengajuan Keberatan Dan Penitipan Ganti Kerugian Ke Pengadilan Negeri Dalam Pengadaan Tanah Bagi Pembangunan Untuk Kepentingan Umum

Peraturan Kepala Badan Pertanahan Nasional Republik Indonesia Nomor 3 Tahun 2007 Tentang Ketentuan Pelaksanaan Peraturan Presiden Nomor 36 Tahun 2005 Tentang Pengadaan Tanah Bagi Pelaksanaan Pembangunan Untuk Kepentingan Umum Sebagaimana Telah Diubah Dengan Peraturan Presiden Nomor 65 Tahun 2006 Tentang Perubahan Atas Peraturan Presiden Nomor 36 Tahun 2005 Tentang Pengadaan Tanah Bagi Pelaksanaan Pembangunan Untuk Kepentingan Umum

Peraturan Presiden Republik Indonesia Nomor 65 Tahun 2006 Tentang Perubahan Atas Peraturan Presiden Nomor 36 Tahun 2005 Tentang Pengadaan Tanah Bagi Pelaksanaan Pembangunan Untuk Kepentingan Umum

Peraturan Presiden Nomor 3 Tahun 2016 tentang percepatan pelaksanaan proyek strategis nasional

Keputusan Presiden Republik Indonesia Nomor 55 tahun 1993 tentang tata cara pembebasan lahan

Instruksi Presiden Republik Indonesia Nomor 1 Tahun 2016 Tentang Percepatan Pelaksanaan Proyek Strategis Nasional

\section{Website}

https://news.detik.com/kolom/d-4021236/pembangunan-infrastruktur-danpartisipasi-masyarakat di akases pada tanggal 10 april 2019, Pukul 15.22 WIB

https://setkab.go.id/komitmen-pemerintah-dalam-penyediaan-infrastruktur-perpresnomor-3-tahun-2016-dan-inpres-nomor-1-tahun-2016/, di akses pada tanggal 10 April 2019, Pukul 13.00 WIB 